\title{
Current antibiotic treatment and outcome for lower respiratory tract infections
}

\author{
Alasdair P MacGowan BMedBiol (Hons) MD MRCPath, Tracey Halladay RGN, Andrew M Lovering BSc PhD
}

\begin{abstract}
AP MacGowan, T Halladay, AM Lovering. Current antibiotic treatment and outcome for lower respiratory tract infections. Can J Infect Dis 1998;9(Suppl E):30E-34E.

A number of national guidelines have been published to aid the antimicrobial management of community-acquired pneumonia. However, data on prescriptions for lower respiratory tract infection (LRTI) indicate considerable variation in the choice of first-line and subsequent therapy at national and local levels. Outcomes research in LRTI, whether based on clinical, economic or patient-focused criteria, is still evolving. Clinical outcomes are best studied for both pneumonia and exacerbation of chronic obstructive pulmonary disease. Economic evaluations often do not encompass all of the costs, for example, time off from work or the economic impact of antibacterial resistance. Duration of hospital stay is a good marker of costs for hospital providers and may be affected by age, marital status and comorbidities. Antibiotic choice may have an impact on the duration of hospital stay by increasing side effects, predisposing patients to hospitalacquired infection or reduced clinical efficacy. Patient expectation is largely unstudied in pulmonary infection.
\end{abstract}

Key Words: Economic evaluations, Lower respiratory tract infection, National guidelines, Outcomes research

\section{Le traitement antibiotique actuel et ses résultats dans l'infection des voies respiratoires inférieures}

\begin{abstract}
RÉSUMÉ : Un certain nombre de directives nationales ont été publiées pour faciliter le traitement antibiotique de la pneumonie extra-hospitalière. Par contre, dans les cas d'infection des voies respiratoires inférieures (IVRI), les statistiques sur les ordonnances témoignent d'une grande variabilité quant au choix des traitements de première intention et autres, à l'échelon local et national. Dans les cas d'IVRI, les recherches se poursuivent pour mesurer l'efficacité des traitements, qu'elle se fonde sur des critères cliniques, économiques ou propres aux patients. C'est dans les cas de pneumonie et d'exacerbation de la bronchopneumopathie obstructive chronique que l'on arrive le mieux à évaluer l'issue thérapeutique. Les évaluations économiques n'englobent souvent pas tous les coûts, par exemple l'absentéisme au travail, l'impact économique de la résistance aux antibactériens; la durée du séjour hospitalier est un bon marqueur des coûts pour les prestateurs du milieu hospitalier et peut subir l'influence de facteurs tels que l'âge, l'état civil et les comorbidités. Le choix de l'antibiotique peut exercer un impact sur la durée du séjour hospitalier en raison de l'augmentation des effets secondaires qui prédisposent les patients aux infections nosocomiales ou en raison d'une baisse de l'efficacité clinique. Les attentes des patients sont largement négligées dans les études sur l'infection pulmonaire.
\end{abstract}

$\mathrm{L}$ ower respiratory tract infection (LRTI) is one of the most common indications for antimicrobial chemotherapy, in both the community and hospital. As an aid to prescribing, many national societies of respiratory medicine and antimi- crobial chemotherapy have produced guidelines for the management of pulmonary infection. It is, however, unclear what effect these guidelines may have on day-to-day patient management beyond isolated reports, and it is unknown what ele-

Bristol Centre for Antimicrobial Research \& Evaluation, Department of Medical Microbiology, Southmead Hospital, Westbury-on-Trym, Bristol, United Kingdom

Correspondence: Dr AP MacGowan, Department of Medical Microbioloby, Southmead Hospital, Westbury-on-Trym, Bristol S10 5NB, United Kingdom. Telephone 011441179595652 , fax 011441179593154 
ments guidelines should contain to ensure maximum prescriber impact (1). It is difficult to give clear recommendations about the use of individual antimicrobials when data that assess outcomes from a clinical, economic or human point of view are collected poorly. We summarize the basic elements of some of the guidelines on therapy and compare this with the information available on antibiotic use in pulmonary infection at a national and local level. In addition, various outcome measures are discussed and ways in which antimicrobial choice can affect outcome measures are illustrated.

National guidelines for the management of communityacquired pneumonia have been published in the United Kingdom (2), United States (3), Canada (4) and South Africa (5). Most of these guidelines are designed to provide advice on management of patients in the community and hospital, although guidelines for the United Kingdom include only hospital in-patients. Most guidelines stratify patients based on clinical severity, but may also include age (for example, United States, Canada, South Africa). The British Thoracic Society statement recommends the use of named individual antibiotics and discourages the use of others. The North American guidelines concentrate on recommending drug classes rather than individual agents. Evidence-based assessment of background information is largely lacking in the United Kingdom and North American guidelines, but was attempted in the South African guidelines. To date, no guidelines have included an indication as to whether the groups' recommendations are extensively supported by scientific or clinical data, or just opinion. The number of references quoted varies from nine (Canada) to 88 (South Africa). Fein and Neiderman (7) highlight many criticisms of the American Thoracic Society guidelines; most of these criticisms are equally valid for the other guidelines. Perhaps most important for community practice, guidelines do not address the issue of patient education. This is vital because patient expectation about their management has a significant impact on prescribing practices (8-10).

The failure of most guidelines to recommend specific drugs, compounded by the large number of antimicrobials available for use in LRTI (Table 1) and exclusion of patient factors, causes prescribing practices to vary widely, even when guidelines are used.

A recent review by Ortqvist (12) illustrates this variation. Data collected by Intercontinental Medical Statistics Ltd, London, United Kingdom defined the top four drugs prescribed for treatment of out-patient pneumonia in seven European countries: France, Germany, Italy, the Netherlands, Spain, Sweden and the United Kingdom. In different countries, different groups of prescribers were included; only general practitioners were included in some countries, whereas general practitioners plus specialists in a variety of practice settings were included in others. Furthermore, different countries use different International Classification of Diseases-9 codes to define pulmonary infection, and the number of antibiotics available varies; however, some broad patterns have emerged (Table 2). Amoxicillin is among the top four agents used in France, the Netherlands, Spain, Sweden and the United Kingdom. Eryth-
TABLE 1

Therapeutic choices in lower respiratory tract infection (oral or intravenous)

\begin{tabular}{lc}
\hline Drug & Alternatives \\
\hline Penicillins & Amoxicillin \\
Amoxicillin-clavulanate & Ampicillin and esters \\
Ampicillin-sulbactam & Piperacillin-tazobactam \\
Ticarcillin-clavulanate & Cefuroxime \\
Cefaclor \\
Cefprozil \\
Loracarbef \\
Ceftibuten \\
Cefixime \\
Cefpodoxime \\
Ceftriaxone \\
Ceftizoxime \\
Cefotaxime \\
Ceftazidime \\
Erythromycin \\
Clarithromycin \\
Azithromycin \\
Dirithromycin \\
Roxithromycin \\
Ciprofloxacin \\
Lomefloxacin \\
Ofloxacin \\
Sparfloxacin \\
Levofloxacin \\
Grepafloxacin \\
(Trovafloxacin) \\
Doxycycline \\
Tetracycline \\
Co-trimoxazole \\
Aminoglycosides \\
Aztreonam \\
Macrolides
\end{tabular}

Agents in brackets recently available or soon to be available. Adapted from (11)

romycin and tetracycline are among the top four agents prescribed in four of the seven countries studied, and co-amoxiclav is among the top four in three countries. Ceftriaxone is among the top four agents prescribed in Italy and France. Cefuroxime-axetil, penicillin, roxithromycin, ceftazidime, imipenem, cefonicid, cefaclor, cefpodoxine and cefotaxime are among the top four most commonly used agents in any one country (any one of these comes within the first four in ranked order). All of the top four agents prescribed in Italy are parenteral, while in most other European countries all of the top four agents are oral. In addition, three of the top four drugs prescribed in Italy are cephalosporins, while no agents in the Netherlands, Sweden or the United Kingdom are cephalosporins (Table 2). In some countries, many drugs have a small market share, while in other countries, a particular drug may have a large market share; in Germany, the top drug, cefuroxime-axetil, accounts for $7 \%$ of treatments, while in Sweden the top drug, penicillin V, accounts for $47 \%$. Quinolone use is rare in all countries. Empirical therapy of 
TABLE 2

Treatment of community-acquired pneumonia in the community: Top four agents used for out-patient management in selected European countries

\begin{tabular}{|c|c|c|c|c|c|c|c|}
\hline & France & Germany & Italy & Netherlands & Spain & Sweden & United Kingdom \\
\hline Amoxicillin & + & - & - & + & + & + & + \\
\hline Erythromycin & - & - & - & + & + & + & + \\
\hline Tetracycline & - & + & - & + & - & + & + \\
\hline Co-amoxiclav & + & - & - & + & - & - & + \\
\hline Ceftriaxone & + & - & + & - & - & - & - \\
\hline Cefuroxime-axetil & - & + & - & - & + & - & - \\
\hline Penicillin & - & - & - & - & - & + & - \\
\hline Roxithromycin & - & + & - & - & - & - & - \\
\hline Ceftazidime & - & - & + & - & - & - & - \\
\hline Imipenem & - & - & + & - & - & - & - \\
\hline Cefonicid & - & - & - & - & + & - & - \\
\hline Cefaclor & - & + & - & - & - & - & - \\
\hline Cefpoxime & + & - & - & - & - & - & - \\
\hline Cefotaxime & - & - & + & - & - & - & - \\
\hline
\end{tabular}

Adapted from (12)

TABLE 3

Community antimicrobial management following initial therapy failure

$\begin{array}{r}\text { Subsequent therapy in patients who failed } \\ \text { initial therapy }(\mathbf{n})\end{array}$
$\begin{aligned} & \text { Amoxicillin (429) } \\ & \text { Erythromycin (74) }\end{aligned}$
$\begin{array}{r}\text { Amoxicillin, co-amoxiclav, erythromycin, } \\ \text { ciprofloxacin, tetracycline (32) } \\ \text { Amoxicillin, co-amoxiclav, ofloxacin, } \\ \text { ciprofloxacin (5) }\end{array}$
Erythromycin, amoxicillin, clarithromycin,
ciprofloxacin (8)

\section{TABLE 4}

Hospital admissions, duration of stay and hospital cost related with age in patients with lower respiratory tract infection

\begin{tabular}{lccc}
\hline $\begin{array}{l}\text { Age group } \\
\text { (years) }\end{array}$ & $\begin{array}{c}\text { Admissions per } \\
\mathbf{1 0 0 0} \text { population } \\
\text { per year }\end{array}$ & $\begin{array}{c}\text { Mean stay } \\
\text { (days) }\end{array}$ & $\begin{array}{c}\text { Cost per 1000 } \\
\text { population per } \\
\text { year } \mathbf{\$} \text { ) }\end{array}$ \\
\hline $16-40$ & 1.37 & 5.2 & 1,370 \\
$40-49$ & 2.00 & 10.0 & 3,800 \\
$50-59$ & 3.94 & 11.4 & 8,548 \\
$60-69$ & 8.42 & 15.3 & 24,580 \\
$70-79$ & 19.98 & 16.8 & 64,370 \\
Older than 79 & 37.74 & 21.2 & 153,278 \\
\hline
\end{tabular}

Data from Southmead Hospital and Shirehampton Health Centre, Bristol, United Kingdom

community-acquired pneumonia in hospitals has also been compared in Italy, Sweden and the United Kingdom; in the United Kingdom, the most frequently used agents are amino penicillins, in Sweden penicillin, and in Italy cephalosporins. In the United Kingdom, 33\% of patients receive a macrolide; in Sweden and Italy less than $15 \%$ receive macrolides. Combination antibiotic use is five times more common in the United Kingdom than in Sweden and eight times more common in Italy than in Sweden (12). Variations in the use of intravenous therapy or oral therapy are not well studied; however, data to support the increased use of oral therapy now exist $(13,14)$.

In the United Kingdom, amoxicillin is the antibiotic most commonly used to treat pneumonia, accounting for $67 \%$ to $80 \%$ of community use ( 15 , unpublished data); however, there is less certainty on the first and second follow-up prescription for those who receive further therapy. Erythromycin is commonly used (43\%) at first follow-up, but cephalosporins or cotrimoxazole are used in $20 \%$ of patients. On second follow-up, quinolones are also used commonly (15). The authors' experience in a Bristol community health centre, indicated that a wide range of agents are used to treat patients who return within 14 days of LRTI diagnosis (Table 3). Therefore, despite the development and publication of guidelines for the management of pneumonia, considerable international variation in prescribing practice clearly exists, both in the community and in hospital. Even in countries such as the United Kingdom, where many patients in community practice receive a single drug (amoxicillin) when patients return and receive a further prescription, there is a high degree of variability in the agent chosen. These variations may be related in part to the poor definition of outcomes in LRTI that make comparison difficult, and the use of different patient stratifications and management strategies.

Outcomes can be divided into three areas - clinical, economic and patient-focused (16). The definition of clinical outcomes has long been a problem in assessing antimicrobial chemotherapy in acute infective exacerbation of chronic obstructive pulmonary disease (COPD). In general, antimicrobial effectiveness can be assessed by using sputum microbiology, speed of recovery from symptoms, time until next exacerbation, subsequent antimicrobial therapy and quality of life. Not all patients with acute exacerbations require antibiotics, and, therefore, it is also important to stratify patients in clinical trials (17-19). When attempting to predict repeat consultation with a chest problem, a history of cardiopulmonary disease and four or more previous exacerbations in the past two months were the best predictors (19). However, patient expec- 
TABLE 5

Influence of Clostridium difficile infection on duration of stay in patients with lower respiratory tract infection

\begin{tabular}{lcc}
\hline Time period & $\begin{array}{c}\text { Duration of stay - mean }(\mathbf{9 5} \% \mathrm{CI}) \\
\text { No C difficile } \\
\text { infection }\end{array}$ & $\begin{array}{c}\text { C difficile } \\
\text { infection }\end{array}$ \\
\hline $\begin{array}{l}\text { Patients treated according to British Thoracic Society } \\
\text { dominately with second generation cephalosporins }\end{array}$ \\
May 1994 - October 1994 & $15(10-18)^{*}$ & $50(25-75)$ \\
November 1994-April 1995 & $14(11-17)^{*}$ & $37(27-47)$ \\
May 1995-October 1995 & $9(7-11)^{*}$ & $25(15-35)$ \\
November 1995-April 1996 & $10(8-12)^{*}$ & $26(16-35)$ \\
Following change in antibiotic policy to ciprofloxacin/penicillin \\
May 1996-October 1996 & $11(9-13)^{*}$ & $26(16-36)$ \\
November 1996-April 1997 & $10(8-12)^{*}$ & $25(21-29)$ \\
\hline
\end{tabular}

* Significant difference $P<0.05$

tation of the consultation process and disease management issues plays a major role (15). In addition, choice of antimicrobial has an effect on the infection-free period in those with COPD. Ciprofloxacin, ampicillin and bacampicillin have similar infection-free periods, while doxycycline, minocycline, trimethoprim/sulphamethoxazole, cephalexin and cefaclor have shorter infection-free periods $(20,21)$. In patients with community-acquired pneumonia, a variety of end-points have been used to assess outcomes including resolution of clinical signs, mortality, radiology, resolution of laboratory abnormalities, pathogen clearance on microbiology, use of second-line antimicrobial therapy, period of hospital stay and supurative complications.

Cost management has become increasingly important in the study of LRTI and has been subdivided into antibiotic costs, office or out-patient visiting, hospital admission and time off work (22). However, it is often difficult to collect all information on the factors related to economic outcome, and important costs such as time off from work are often excluded (23). The impact that therapy has on antimicrobial resistance is almost always unevaluated in economic studies, probably because the costs are too difficult to calculate (24). In the hospital sector, the main provider costs are related to duration of stay. Although this is a crude measure, it probably identifies most of the costs. The more general costs to society and the patient are partially excluded, but factors that affect duration of stay (for example, age, marital status, comorbidity) influence costs and have a major economic impact. Patients with COPD and diabetes have increased hospital stays compared with controls, while asthmatics with LRTI may have shorter stays (25, unpublished data). Because of the higher number of hospital admissions and longer duration of stay in the elderly, age is a main cost determinant (Table 4). An understanding of the factors related to hospital admission and identifying which factors have an impact on length of stay will help to manage hospital costs in LRTI.

The authors have shown that acquisition of Clostridium difficile infection in Southmead Hospital is related to the use of cefuroxime for treatment of pulmonary infection (26); the
TABLE 6

Incidence of Clostridium difficile infection in patients with lower respiratory tract infection and percentage of bed days attributed to those with infection

\begin{tabular}{|c|c|c|}
\hline Time period & $\begin{array}{l}\text { Patients admitted } \\
\text { with LRTI who } \\
\text { contracted } \\
\text { C difficile infection } \\
(\%)\end{array}$ & $\begin{array}{l}\text { Total bed days oc- } \\
\text { cupied by those } \\
\text { with } C \text { difficile in- } \\
\text { fection associated } \\
\text { with LRTI (\%) }\end{array}$ \\
\hline \multicolumn{3}{|c|}{$\begin{array}{l}\text { Patients treated according to British Thoracic Society guidelines, pre- } \\
\text { dominately with } 2 \text { nd generation cephalosporins }\end{array}$} \\
\hline $\begin{array}{l}\text { May 1994-October } \\
1994\end{array}$ & 12 & 31 \\
\hline $\begin{array}{l}\text { November 1994-April } \\
1995\end{array}$ & 15 & 32 \\
\hline $\begin{array}{l}\text { May 1995-October } \\
1995\end{array}$ & 12 & 27 \\
\hline $\begin{array}{l}\text { November 1995-April } \\
1996\end{array}$ & 18 & 34 \\
\hline \multicolumn{3}{|c|}{ Following change in antibiotic policy to ciprofloxacin/penicillin } \\
\hline $\begin{array}{l}\text { May } 1996 \text {-October } \\
1996\end{array}$ & 7 & 14 \\
\hline $\begin{array}{l}\text { November 1996-April } \\
1997\end{array}$ & 4 & 9 \\
\hline
\end{tabular}

risk being related to both the duration and course of the dose. While the duration of stay of all patients with chest infection admitted to Southmead Hospital has fallen since 1994, those who have $C$ difficile infection still stay in hospital about twice as long as those without (Table 5) (27). In April 1996, the authors substituted ciprofloxacin plus penicillin for cefuroxime in the protocol for the treatment of chest infection, a change that is not consistent with the British Thoracic Society guidelines. Ciprofloxacin was selected because quinolones seem less likely to be associated with $C$ difficile infection. Over the next year, cefuroxime use in patients with chest infection dropped by $90 \%$; ciprofloxacin use increased 10 -fold. This was associated with a fourfold reduction in the percentage of patients acquiring $C$ difficile in hospital and a reduction by onethird in the number of lower respiratory tract bed days occupied by those who contracted $C$ difficile (Table 6$)(26,28)$. Data on how antibiotic choice affects length of stay related to other side effects or difference in clinical efficacy are unclear.

In addition to the better studied clinical and economic aspects, it is now becoming apparent that patient expectation and understanding of the natural course of LRTI are important factors in disease management, especially in those with chronic disease such as COPD. Patient-generated outcome scores based on symptoms, activities and overall well-being can be simple to apply and, while not presently used in pulmonary infection, have definite advantages (29).

\section{CONCLUSIONS}

There are considerable differences between day-to-day practice and antimicrobial practice as recommended by several countries' national guidelines. Several countries' national guidelines often recommend drug classes rather than individ- 
ual agents, probably because outcome measures in clinical, economic or patient terms do not allow adequate differentiation between classes or individual drugs. If there is a clear relationship between the use of an agent and an adverse outcome, modification of prescribing can have significant favourable effects. However, given the complexity of factors in determining clinical and economic outcomes, such situations are rare. In community-based prescribing for LRTI, patient expectation is an important factor in antibiotic use; however, its role in hospital is unquantified.

\section{REFERENCES}

1. Bateman KA, Dean NC, Hadlock CJ, Golubjatnikov OK, James BC. Use of a care process model for community-acquired pneumonia in a rural area. Chest 1996;110:30S

2. Guidelines for the management of community acquired pneumonia in adults admitted to hospital. The British Thoracic Society. Br J Hosp Med 1993:49:346-50.

3. Guidelines for the initial management of adults with community acquired pneumonia: diagnosis, assessment of severity and initial antimicrobial therapy. American Thoracic Society. Am Rev Respir Dis 1993;148:1418-26.

4. Mandell LA, Niederman M, The Canadian Community Acquired Pneumonia Consensus Conference Group. Antimicrobial treatment of community acquired pneumonia in adults: A conference report. Can J Infect Dis 1993;4:25-8.

5. Management of community acquired pneumonia in adults. Working Groups of the South African Pulmonology Society and Antibiotic Study Group of South Africa. S Afr Med J 1996;86:1152-63.

6. Bartlett JG, Breiman RF, Mandel LA, File TM Jr. Community-acquired pneumonia in adults: guidelines for management. The Infectious Diseases Society of America. Clin Infect Dis 1998;26:811-38.

7. Fein AM, Niederman MS. Guidelines for the initial management of community acquired pneumonia: savoury recipe or cookbook for disaster? Am J Respir Crit Care Med 1995;152:1149-53.

8. Macfarlane J, Prewett J, Rose D, et al. Prospective case-control study of role of infection in patients who reconsult after initial antibiotic treatment for lower respiratory tract infection in primary care. BMJ 1997;315:1206-10.

9. Macfarlane J, Holmes W, Macfarlane R, Britten N. Influence of patients' expectations on antibiotic management of acute lower respiratory tract illness in general practice: questionnaire study. BMJ 1997;315:1211-4.

10. Britten $\mathrm{N}$, Ukoumunne 0 . The influence of patients' hopes of receiving a prescription on doctors' perceptions and the decision to prescribe: a questionnaire survey. BMJ 1997;315:1506-10.

11. Norman DC, Bradley SF, Dorinsky PM, Verghese A. Treating respiratory infections in the elderly: current strategies and considerations. Geriatrics 1997;52(Suppl 1):S1-28.
12. Ortqvist A. Antibiotic treatment of community-acquired pneumonia in clinical practice: a European perspective. J Antimicrobial Chemother 1995;35:205-12.

13. Chan R, Hemeryck L, O'Regan M, Clancy L, Feely J. Oral versus intravenous antibiotics for community acquired lower respiratory tract infection in a general hospital: open randomised controlled trial. BMJ 1995;310:1360-2.

14. Hamilton-Miller JMT. Switch therapy, the theory and practice of early change from parenteral to non-parenteral antibiotic administration. Clin Microbiol Infect 1996;2:12-9.

15. Macfarlane JT, Colville A, Guion A, Macfarlane RM, Rose DH. Prospective study of aetiology and outcome of adult lower-respiratory-tract infections in the community. Lancet 1993;341:511-4.

16. Bootman JL, Milne RJ. Costs, innovation and efficiency in anti infective therapy. Pharmacoeconomics 1996;9:(Suppl 1):31-9.

17. Wilson R. Outcome predictors in bronchitis. Chest 1995;108(Suppl 2):53S-7S

18. Ball P. Epidemiology and treatment of chronic bronchitis and its exacerbations. Chest 1995;108(Suppl 2):43S-52S.

19. Ball P, Harris JM, Lowson D, Tillotson G, Wilson R. Acute infective exacerbations of chronic bronchitis. QJM 1995;88:61-8.

20. Chodosh S. Acute bacterial exacerbations in bronchitis and asthma. Am J Med 1987;82(Suppl 4A):154-63.

21. Chodosh S. Treatment of acute exacerbations of chronic bronchitis: state of the art. Am J Med 1991;91(Suppl $6 \mathrm{~A}): 87 \mathrm{~S}-92 \mathrm{~S}$

22. Davey PG. Cost management in community-acquired lower respiratory tract infection. Am J Med 1995;99(Suppl 6B):20S-3S

23. Backhouse R, Shakespeare A, Hutton J. Economic evaluation of alternative antibiotic regimens in the management of acute exacerbations of chronic bronchitis. Br J Med Econ 1995;8:11-25.

24. Coast J, Smith RD, Millar MR. Superbugs: should antimicrobial resistance be included as a cost in economic evaluation. Health Econ 1996;5:217-26.

25. Loukides S, Polyzogopoulos D. The effect of diabetes mellitus on the outcome of patients with chronic obstructive pulmonary disease exacerbated due to respiratory infections. Respiration 1996;63:170-3.

26. MacGowan AP, Feeney R, Brown I, McCulloch SY, Reeves DS, Lovering AM. Healthcare resource utilisation and antimicrobial use in elderly patients community-acquired lower respiratory tract infection who develop Clostridium difficile-associated diarrhoea. J Antimicrob Chemother 1997;39:537-41.

27. MacGowan AP, Brown I, Feeney R, et al. Clostridium difficile-associated diarrhoea and length of hospital stay. J Hosp Infect $1995 ; 31: 241-4$.

28. Jones EM, Kirkpatrick BL, Feeney R, Reeves DS, MacGowan AP. Hospital-acquired Clostridium difficile diarrhoea. Lancet 1997;349:1176-7.

29. Paterson C. Measuring outcomes in primary care: a patient generated measure, MYMOP, compared with the SF- 36 health survey. BMJ 1996;312:1016-20. 


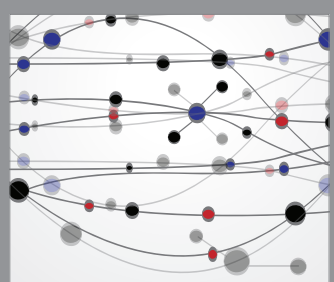

The Scientific World Journal
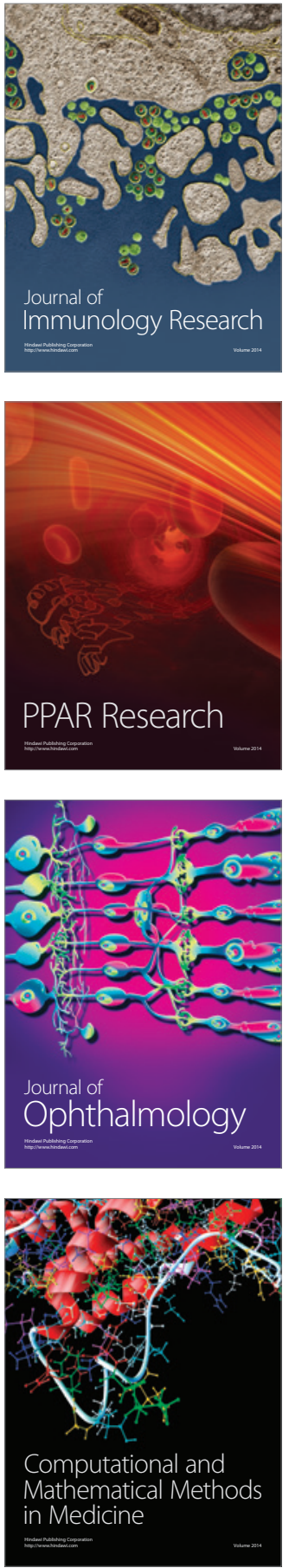

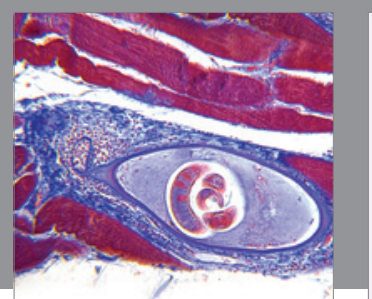

Gastroenterology Research and Practice

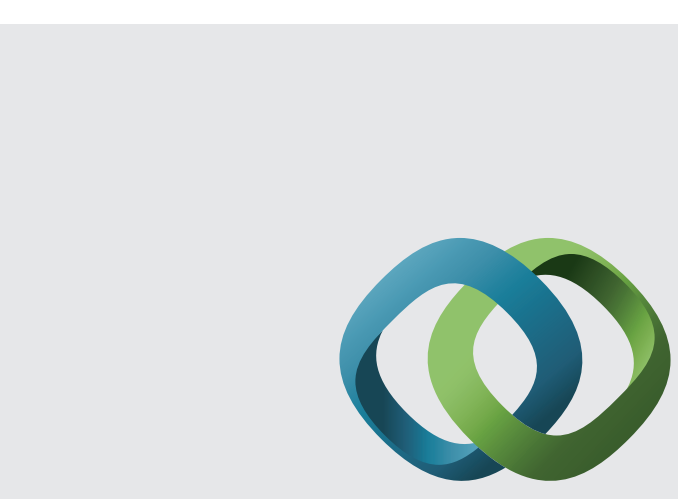

\section{Hindawi}

Submit your manuscripts at

http://www.hindawi.com
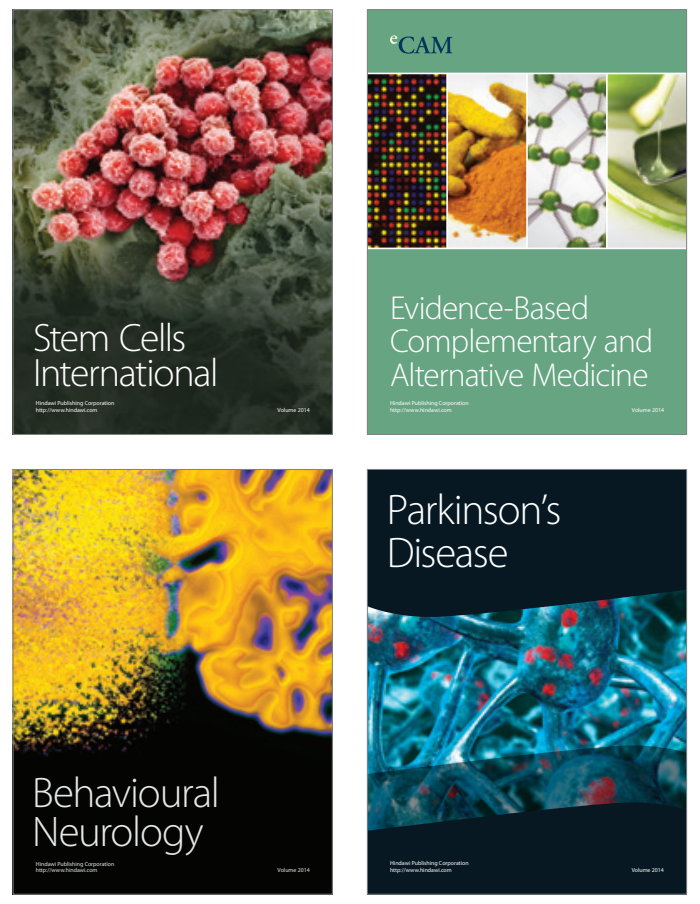
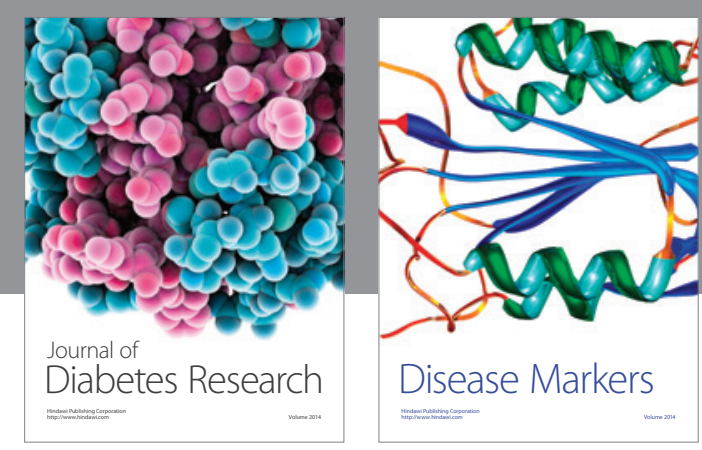

Disease Markers
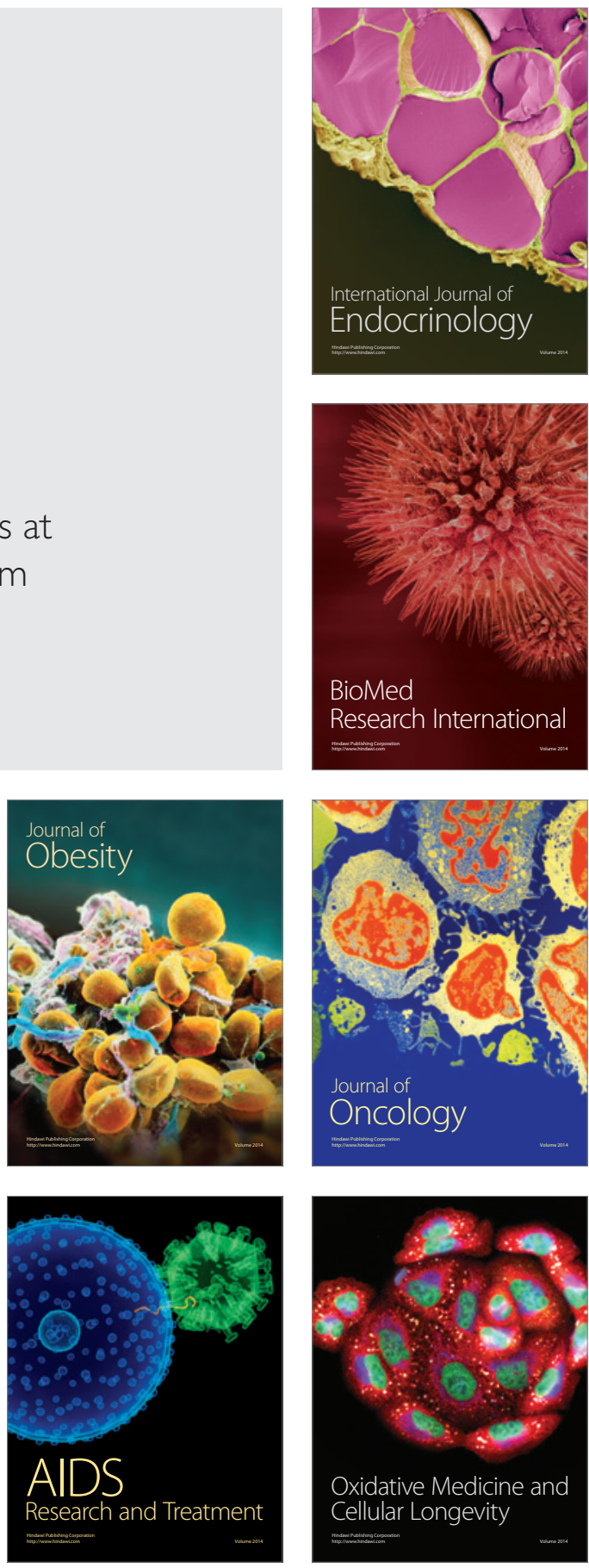